\title{
Estimation the annual dose for residents in the area around the berms of Al-Tuwaitha nuclear site using RESRAD software
}

\author{
Hussein Jabbar Mugar and Mahdi Hadi Jasim \\ Department of Physics, College of Science, University of Baghdad \\ E-mail: husein_alshamsee@yahoo.com
}

\begin{abstract}
RESRAD is a computer model designed to estimate risks and radiation doses from residual radioactive materials in soil. Thirty seven soil samples were collected from the area around the berms of Al-Tuwaitha site and two samples as background taken from an area about $3 \mathrm{~km}$ north of the site. The samples were measured by gammaray spectrometry system using high purity germanium ( $H P G e)$ detector. The results of samples measurements showed that three contaminated area with ${ }^{238} \mathrm{U}$ and ${ }^{235} \mathrm{U}$ found in the study area. Two scenarios were applied for each contaminated area to estimate the dose using RESRAD (onsite) version 7.0 code. The total dose of resident farmer scenario for area $\mathrm{A}, \mathrm{B}$ and $\mathrm{C}$ are $0.854,0.033$ and $2.15 \times 10^{-3} \mathrm{mSv} \cdot \mathrm{yr}^{-1}$, respectively. While suburban resident scenario for area A, B and $\mathrm{C}$ are $0.807,0.031$ and $2.04 \times 10^{-3} \mathrm{mSv}_{\mathrm{yr}}{ }^{-1}$, respectively.
\end{abstract}

Key words

Annual dose, RESRAD, Al-

Tuwaitha nuclear site.

Article info.

Received: Sep. 2017

Accepted: Nov. 2017

Published: Jun. 2018

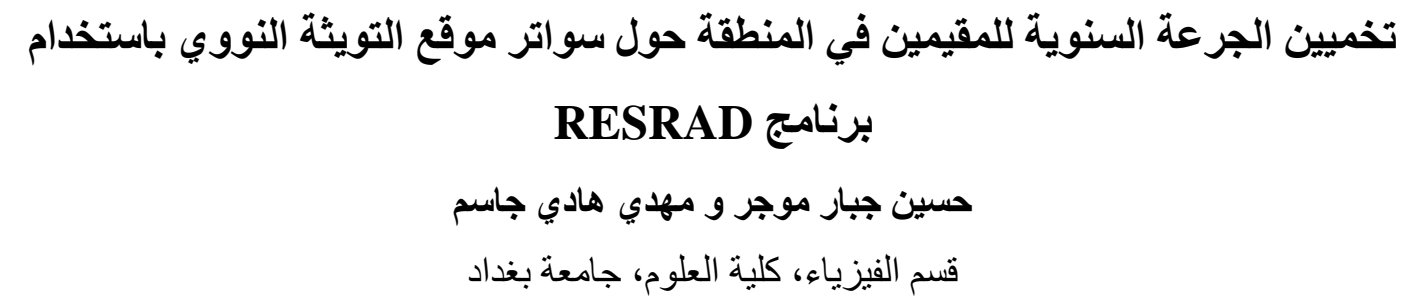

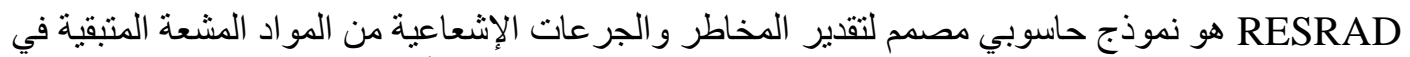

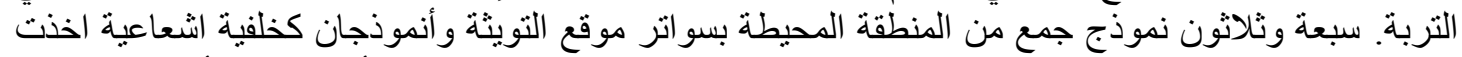

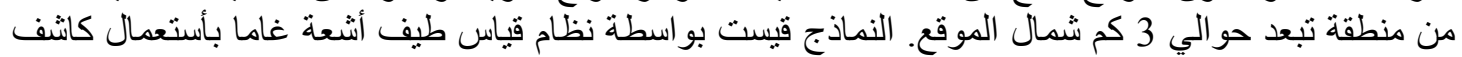

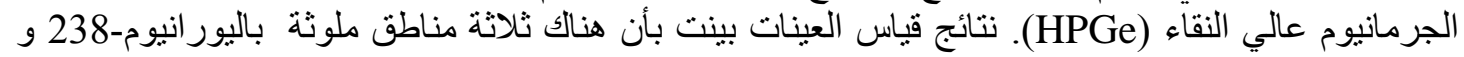

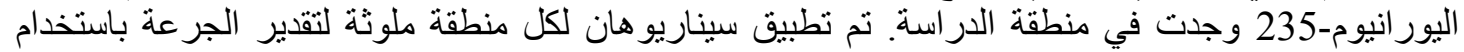
RESRAD (onsite)

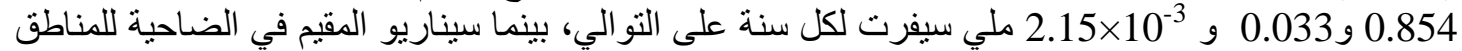

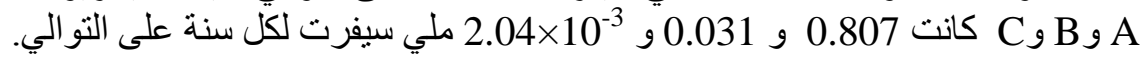

\section{Introduction}

One of the most important steps in protecting human health in the contamination areas with radioactive matirail is to determine how these radionuclides may eventually reach people and thus cause them harm [1]. Evaluation of the impact of radionuclide releases on humans and on the environment is important, both to quantify the risks which arise from radionuclides present in the environment due to past human activities and to predict the possible future risks. The risks from these releases arise as a result of the 
transport of radionuclides in air, water, soils, or food from their release point to human [2]. Given that calculations for risk and dose assessments are complex, they are best done on a computer. RESRAD is a computer model designed to estimate risks and radiation doses from residual radioactive materials. RESRAD (short for residual radioactivity) was first released in 1989 and developed by Argonne national laboratory. It is a multifunctional tool to assist in developing cleanup criteria and assessing the risk and dose associated with residual radioactive material in soil [3]. The exposure pathways considered by RESRAD include (1) external radiation, (2) inhalation of radon or other gaseous radionuclides and contaminated dirt, (3) ingestion of contaminated plants, meat, aquatic foods, and soil, and (4) drinking contaminated water and milk [1].

\section{The studied area}

Al-Tuwaitha nuclear research center is considered the biggest and most complex nuclear facility in Iraq. It is located about $1 \mathrm{~km}$ east of the Tigris River and $3 \mathrm{~km}$ south of the southern edge of Baghdad. The facilities in AlTuwaitha cover approximately $1.2 \mathrm{~km}^{2}$ and surrounding by earthen security berm with an approximately $4.6 \mathrm{~km}$ long and $30 \mathrm{~m}$ high and contain three gaps which allow for vehicle access. In 1991 and during the Gulf War, most of these facilities were extensively destroyed [4]. The area around the berms of Al-Tuwaitha site involved an area approximately $12 \mathrm{~km}^{2}$. It is contained Ishtar village, military barracks, farms and a wide area not occupied by people. Therefore, it is important to evaluate the annual dose for those populations who resident in present time and those will resident in future. The dose for this area should not exceed the limits for public which recommendation by regulatory control.

\section{Collection samples}

Two soil samples were taken from the area located approximately $3 \mathrm{~km}$ north of the site in order to establish background level. 37 soil samples were collected from the area around the berms of Al-Tuwaitha site. Fig.1 shows the location of samples in the area around the berms of Al-Tuwaitha site and background samples. The samples were taken at $15 \mathrm{~cm}$ depth from the top surface soil layer to make approximately $1.5 \mathrm{~kg}$ weight per sample, using trowel tool. Each soil sample is filled into secure polyethylene bag with sealable tops to prevent cross contamination and sent to the laboratory. The soil sample is contained label recorded in it the information about the sample such as code, sample type, data of collected, location and GPS coordinates. The samples dried, grinded, sieved, filled into $500 \mathrm{ml}$ Marinelli beakers and stored for about one month to obtain the radioactive secular equilibrium between parent and their daughter radionuclides. Samples were measured by gamma-ray spectrometry system using high purity germanium (HPGe) detector with relative efficiency $65 \%$. To determine the radionuclides in soil samples, the energy $1001.03 \mathrm{keV}$ $\left({ }^{234 \mathrm{~m}} \mathrm{~Pa}\right)$ used for ${ }^{238} \mathrm{U}, 911.20 \mathrm{keV}$ $\left({ }^{228} \mathrm{Ac}\right)$ for ${ }^{232} \mathrm{Th}, 609.31 \mathrm{keV}\left({ }^{214} \mathrm{Bi}\right)$ for ${ }^{226} \mathrm{Ra}, 163.76$ and $205.31 \mathrm{keV}$ used for $\left({ }^{235} \mathrm{U}\right),{ }^{40} \mathrm{~K}$ at $1460.81 \mathrm{keV}$ and ${ }^{137} \mathrm{Cs}$ at $661.65 \mathrm{keV}$ were used. 


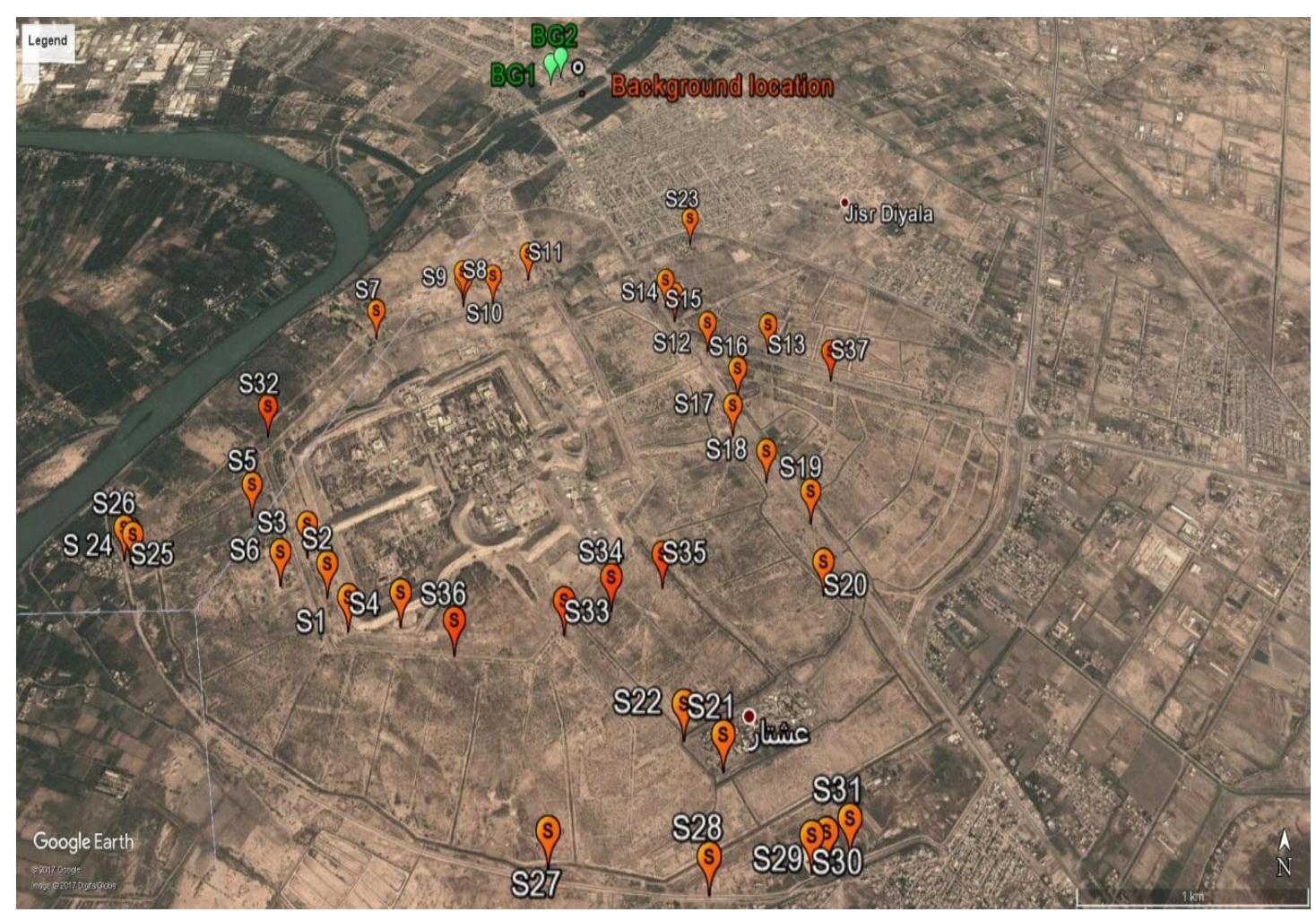

Fig.1: The location of samples in the area around the berms of Al-Tuwaitha site and background samples.

The radionuclide concentration in the soil sample

The specific activity of ${ }^{238} \mathrm{U},{ }^{235} \mathrm{U}$, ${ }^{232} \mathrm{Th},{ }^{226} \mathrm{Ra},{ }^{40} \mathrm{~K}$ and ${ }^{137} \mathrm{Cs}$ for all soil samples are given in Table 1 . According to results of the samples measured in gamma spectrometer.
There are three areas contaminated with uranium component $\left({ }^{238} \mathrm{U}\right.$ and ${ }^{235} \mathrm{U}$ ) which considered clearly above background concentrations were found in the area around the berms and divided according to their location to area A, B and C. Fig. 2 shows the location of contamination areas.

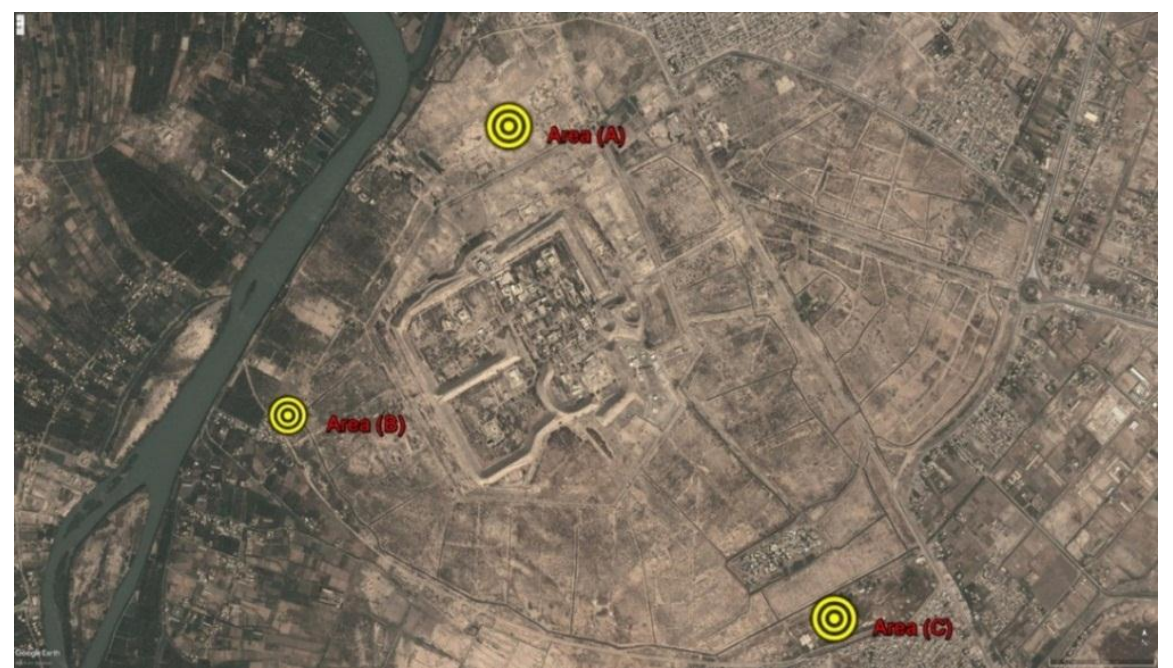

Fig. 2: Location of contamination areas in yellow circles which are clearly above background concentration. Area A includes samples $S-8$ and $S-9$, area $B$ includes samples $S$-24, $S-25$ and $S-26$, and area $C$ includes samples $S-29, S-30$ and $S-31$. 
Table1: The measurements of radionuclides activity in the soil samples.

\begin{tabular}{|c|c|c|c|c|c|c|c|}
\hline \multirow[t]{2}{*}{$\mathrm{N}$} & \multirow{2}{*}{$\begin{array}{c}\text { Sample } \\
\text { code }\end{array}$} & \multicolumn{6}{|c|}{ Activity Concentration (Bq. $\left.\mathrm{kg}^{-1}\right)$} \\
\hline & & ${ }^{238} \mathbf{U}\left({ }^{234 \mathrm{~m}} \mathbf{P a}\right)$ & ${ }^{235} \mathbf{U}$ & ${ }^{232} \mathrm{Th}\left({ }^{228} \mathrm{Ac}\right)$ & ${ }^{226} \mathbf{R a}\left({ }^{214} \mathrm{Bi}\right)$ & ${ }^{40} \mathbf{K}$ & ${ }^{137} \mathrm{Cs}$ \\
\hline 1 & S-1 & $<\mathrm{MDA}$ & $<$ MDA & $19.95 \pm 1.75$ & $18.16 \pm 2.63$ & $383.44 \pm 10.35$ & $3.84 \pm 0.49$ \\
\hline 2 & S-2 & $<$ MDA & $<$ MDA & $15.52 \pm 1.63$ & $18.12 \pm 2.5$ & $372.39 \pm 10.49$ & $<\mathrm{MDA}$ \\
\hline 3 & $\mathrm{~S}-3$ & $<$ MDA & $<$ MDA & $16.74 \pm 1.5$ & $16.54 \pm 2.28$ & $348.6 \pm 9.5$ & $<$ MDA \\
\hline 4 & S-4 & $<$ MDA & $<$ MDA & $18.67 \pm 1.67$ & $18.26 \pm 1.54$ & $341.4 \pm 9.62$ & $5.92 \pm 0.49$ \\
\hline 5 & S-5 & $<$ MDA & $<$ MDA & $18.62 \pm 2.81$ & $19.11 \pm 2.41$ & $409.65 \pm 21.53$ & $<\mathrm{MDA}$ \\
\hline 6 & S-6 & $<\mathrm{MDA}$ & $<$ MDA & $17.65 \pm 1.71$ & $17.53 \pm 1.7$ & $402.92 \pm 9.94$ & $<$ MDA \\
\hline 7 & $\mathrm{~S}-7$ & $<\mathrm{MDA}$ & $<$ MDA & $15.5 \pm 1.49$ & $19.59 \pm 1.82$ & $364.56 \pm 10.08$ & $1.35 \pm 0.34$ \\
\hline 8 & S-8 & $50674 \pm 847.5$ & $1959.5 \pm 29.2$ & $19.19 \pm 5.65$ & $19.02 \pm 1.74$ & $345.63 \pm 24.9$ & $<\mathrm{MDA}$ \\
\hline 9 & S-9 & $7523.6 \pm 152.25$ & $272.54 \pm 5.23$ & $15.9 \pm 1.67$ & $17.24 \pm 1.5$ & $289.9 \pm 8.95$ & $<\mathrm{MDA}$ \\
\hline 10 & S-10 & $<$ MDA & $<$ MDA & $15.05 \pm 1.63$ & $17.6 \pm 1.4$ & $357.67 \pm 9.85$ & $1.29 \pm 0.3$ \\
\hline 11 & S-11 & $<$ MDA & $<$ MDA & $16.22 \pm 1.65$ & $18.73 \pm 1.2$ & $326.76 \pm 9.7$ & $2.95 \pm 0.4$ \\
\hline 12 & S-12 & $<$ MDA & $<$ MDA & $18.2 \pm 3.9$ & $16.32 \pm 2.11$ & $339.5 \pm 20.8$ & $<\mathrm{MDA}$ \\
\hline 13 & S-13 & $<$ MDA & $<$ MDA & $19.14 \pm 3.6$ & $16.82 \pm 1.9$ & $398.9 \pm 22.58$ & $3.24 \pm 1.009$ \\
\hline 14 & S-14 & $<$ MDA & $<$ MDA & $11.4 \pm 2.44$ & $12.78 \pm 2.75$ & $261.1 \pm 16.7$ & $1.11 \pm 0.5$ \\
\hline 15 & S-15 & $<$ MDA & $<$ MDA & $16.87 \pm 3.5$ & $18.12 \pm 1.4$ & $299.67 \pm 19.32$ & $<\mathrm{MDA}$ \\
\hline 16 & S-16 & $<$ MDA & $<$ MDA & $18.4 \pm 4.1$ & $18.4 \pm 2.5$ & $414 \pm 23.07$ & $<\mathrm{MDA}$ \\
\hline 17 & S-17 & $<$ MDA & $<$ MDA & $23.2 \pm 3.85$ & $16.69 \pm 2.3$ & $392.22 \pm 23.6$ & $2.86 \pm 1.04$ \\
\hline 18 & S-18 & $<\mathrm{MDA}$ & $<$ MDA & $14.88 \pm 3.61$ & $17.46 \pm 2.1$ & $343.75 \pm 20.5$ & $<\mathrm{MDA}$ \\
\hline 19 & S-19 & $<$ MDA & $<$ MDA & $16.64 \pm 3.2$ & $16.13 \pm 2.3$ & $332.7 \pm 20.6$ & $<$ MDA \\
\hline 20 & $\mathrm{~S}-20$ & $<$ MDA & $<$ MDA & $16.15 \pm 3.6$ & $16.35 \pm 1.95$ & $371.49 \pm 22.1$ & $<\mathrm{MDA}$ \\
\hline 21 & S-21 & $<\mathrm{MDA}$ & $<$ MDA & $16.69 \pm 1.63$ & $19.84 \pm 1.32$ & $380.95 \pm 10.2$ & $1.62 \pm 0.41$ \\
\hline 22 & S-22 & $<$ MDA & $<$ MDA & $11.26 \pm 0.7$ & $17.53 \pm 1.32$ & $365.4 \pm 10.49$ & $10.7 \pm 0.63$ \\
\hline 23 & S-23 & $<$ MDA & $<$ MDA & $15.72 \pm 1.66$ & $16.08 \pm 1.2$ & $339.8 \pm 10.41$ & $<\mathrm{MDA}$ \\
\hline 24 & S-24 & $196.69 \pm 14.37$ & $9.34 \pm 0.68$ & $16.37 \pm 1.7$ & $19.39 \pm 1.7$ & $406.09 \pm 10.54$ & $<$ MDA \\
\hline 25 & S-25 & $1931.3 \pm 79.19$ & $71.03 \pm 3.2$ & $19.26 \pm 1.8$ & $23.05 \pm 1.8$ & $378.4 \pm 10.2$ & $1.84 \pm 0.3$ \\
\hline 26 & S-26 & $1428.2 \pm 167.3$ & $54.4 \pm 2.7$ & $19.1 \pm 3.9$ & $16.26 \pm 2.8$ & $389.24 \pm 21.4$ & $2.05 \pm 0.84$ \\
\hline 27 & S-27 & $<\mathrm{MDA}$ & $<\mathrm{MDA}$ & $20.15 \pm 2.1$ & $18.19 \pm 1.1$ & $412.2 \pm 10.96$ & $<\mathrm{MDA}$ \\
\hline 28 & S-28 & $<$ MDA & $<$ MDA & $19.13 \pm 1.6$ & $19.49 \pm 1.5$ & $393.59 \pm 9.88$ & $1.48 \pm 0.3$ \\
\hline 29 & S-29 & $28.4 \pm 3.8$ & $3.2 \pm 0.3$ & $19.07 \pm 1.7$ & $18.74 \pm 1.4$ & $381.49 \pm 10.15$ & $6.35 \pm 0.5$ \\
\hline 30 & $\mathrm{~S}-30$ & $78.8 \pm 34.8$ & $5.7 \pm 0.9$ & $17.12 \pm 1.6$ & $18.69 \pm 1.7$ & $341.96 \pm 10.6$ & $<\mathrm{MDA}$ \\
\hline 31 & S-31 & $80.04 \pm 25.02$ & $7.1 \pm 0.8$ & $17.24 \pm 1.7$ & $16.32 \pm 2.3$ & $368.2 \pm 9.8$ & $0.65 \pm 0.2$ \\
\hline 32 & S-32 & $<$ MDA & $<$ MDA & $16.48 \pm 3.4$ & $18.54 \pm 1.9$ & $370.28 \pm 21.7$ & $<\mathrm{MDA}$ \\
\hline 33 & S-33 & $<$ MDA & $<$ MDA & $16.19 \pm 3.7$ & $17.39 \pm 2.6$ & $410.33 \pm 22.39$ & $2.2 \pm 0.7$ \\
\hline 34 & S-34 & $<$ MDA & $<$ MDA & $19.5 \pm 3.3$ & $19.02 \pm 2.1$ & $422.3 \pm 22.9$ & $4.28 \pm 0.96$ \\
\hline 35 & S-35 & $<$ MDA & $<$ MDA & $21.02 \pm 3.7$ & $18.52 \pm 2.2$ & $393.9 \pm 22.3$ & $2.66 \pm 0.91$ \\
\hline 36 & S-36 & $<$ MDA & $<$ MDA & $20.9 \pm 3.6$ & $16.35 \pm 1.9$ & $359.34 \pm 21.7$ & $<\mathrm{MDA}$ \\
\hline 37 & S-37 & $<$ MDA & $<$ MDA & $17.56 \pm 3.6$ & $16.63 \pm 2.1$ & $359.8 \pm 22.12$ & $2.25 \pm 0.8$ \\
\hline 38 & BG-1 & $<$ MDA & $<$ MDA & $17.75 \pm 1.3$ & $19.7 \pm 2.6$ & $395.48 \pm 25.3$ & 2.35 \\
\hline 39 & BG-2 & $<$ MDA & $<$ MDA & $15.48 \pm 1.4$ & $17.97 \pm 2.3$ & $323.73 \pm 19.5$ & $<$ MDA \\
\hline
\end{tabular}




\section{The input parameters of RESRAD}

Resident farmer and suburban resident scenario applied for each contaminated area to evaluate the dose using RESRAD (onsite) version 7.0 codes created in 2014. The Table 2 showed the input parameters values of RESRAD which used to calculate the annual dose of these areas for two scenarios.

\section{Results and discussions}

Table 3 shows the results of RESRAD calculations. The total dose of resident farmer scenario for area A, $\mathrm{B}$ and $\mathrm{C}$ are $0.854,0.033$ and $2.15 \times 10^{-3} \mathrm{mSv} . \mathrm{yr}^{-1}$, respectively. The large contribution of total dose comes from external, plant and soil ingest dose with 88,6 and $4 \%$, respectively.

Table 2: The input parameters for RESRAD used to calculate the dose of contaminated area.

\begin{tabular}{|c|c|c|c|c|c|c|c|}
\hline \multirow[t]{2}{*}{ parameters } & \multirow[t]{2}{*}{ unit } & \multicolumn{2}{|c|}{$\operatorname{Area}(\mathrm{A})$} & \multicolumn{2}{|c|}{$\operatorname{Area}(\mathbf{B})$} & \multicolumn{2}{|c|}{$\operatorname{Area}(C)$} \\
\hline & & $\begin{array}{l}\text { Resident } \\
\text { Farmer }\end{array}$ & $\begin{array}{c}\text { Suburban } \\
\text { Resident }\end{array}$ & $\begin{array}{l}\text { Resident } \\
\text { Farmer }\end{array}$ & $\begin{array}{c}\text { Suburban } \\
\text { Resident }\end{array}$ & $\begin{array}{l}\text { Resident } \\
\text { Farmer }\end{array}$ & $\begin{array}{c}\text { Suburban } \\
\text { Resident }\end{array}$ \\
\hline $\begin{array}{l}\text { Mean radionuclide } \\
\text { concentration@ }\end{array}$ & $\begin{array}{l}\mathrm{Bq} / \mathrm{g} \\
\mathrm{m}\end{array}$ & $\begin{array}{l}29.098 \\
\text { for }{ }^{238} \mathrm{U} \\
1.115 \text { for } \\
{ }^{235} \mathrm{U}\end{array}$ & $\begin{array}{c}29.098 \\
\text { for }{ }^{238} \mathrm{U} \\
1.115 \\
\text { for }{ }^{235} \mathrm{U}\end{array}$ & $\begin{array}{l}1.185 \text { for } \\
{ }^{238} \mathrm{U} \\
0.044 \text { for } \\
{ }^{235} \mathrm{U}\end{array}$ & $\begin{array}{c}1.185 \\
\text { for }{ }^{238} \mathrm{U} \\
0.044 \\
\text { for }{ }^{235} \mathrm{U}\end{array}$ & $\begin{array}{c}0.06256 \\
\text { for }{ }^{238} \mathrm{U} \\
0.0053 \text { for } \\
{ }^{235} \mathrm{U}\end{array}$ & $\begin{array}{c}0.06256 \text { for } \\
{ }^{238} \mathrm{U} \\
0.0053 \\
\text { for }{ }^{235} \mathrm{U}\end{array}$ \\
\hline $\begin{array}{c}\text { Contaminated } \\
\text { area@ }\end{array}$ & $\mathrm{m}^{2}$ & 1250 & 1250 & 500 & 500 & 1000 & 1000 \\
\hline $\begin{array}{c}\text { Thickness of } \\
\text { contaminated@ }\end{array}$ & $\mathrm{m}$ & 0.15 & 0.15 & 0.15 & 0.15 & 0.15 & 0.15 \\
\hline Cover depth@ & $\mathrm{m}$ & 0 & 0 & 0 & 0 & 0 & 0 \\
\hline $\begin{array}{l}\text { Average annual } \\
\text { wind speed [7] }\end{array}$ & $\mathrm{m} / \mathrm{s}$ & 3.1 & 3.1 & 3.1 & 3.1 & 3.1 & 3.1 \\
\hline Precipitation[8] & $\mathrm{m} / \mathrm{yr}$ & 0.152 & 0.152 & 0.152 & 0.152 & 0.152 & 0.152 \\
\hline $\begin{array}{l}\text { Fraction of time } \\
\text { indoors[3] }\end{array}$ & - & 0.50 & 0.50 & 0.50 & 0.50 & 0.50 & 0.50 \\
\hline $\begin{array}{c}\text { Fraction of time } \\
\text { outdoors }[3]\end{array}$ & - & 0.25 & 0.25 & 0.25 & 0.25 & 0.25 & 0.25 \\
\hline Plant food[3] & - & 0.5 & 0.1 & 0.5 & 0.1 & 0.5 & 0.1 \\
\hline Milk[3] & - & 0.1 & Not used & 0.1 & Not used & 0.1 & Not used \\
\hline Meat[3] & - & 0.1 & Not used & 0.1 & Not used & 0.1 & Not used \\
\hline Aquatic food[3] & - & 0.5 & Not used & 0.5 & Not used & 0.5 & Not used \\
\hline Soil ingestion[3] & $\mathrm{g} / \mathrm{yr}$ & 36.5 & 36.5 & 36.5 & 36.5 & 36.5 & 36.5 \\
\hline $\begin{array}{l}\text { Drinking water } \\
\text { intake[3] }\end{array}$ & $\mathrm{L} / \mathrm{yr}$ & 510 & Not used & 510 & Not used & 510 & Not used \\
\hline $\begin{array}{c}\text { Duration } \\
\text { exposure[3] }\end{array}$ & $\mathrm{yr}$ & 30 & 30 & 30 & 30 & 30 & 30 \\
\hline Inhalation rate[3] & $\mathrm{m}^{3} / \mathrm{yr}$ & 8400 & 8400 & 8400 & 8400 & 8400 & 8400 \\
\hline
\end{tabular}

@ Current study 
The total dose for suburban resident scenario for area A, B and C are 0.807, 0.031 and $2.04 \times 10^{-3}$ mSv.yr ${ }^{-1}$, respectively. The large contribution of total dose comes from external, soil ingestion and plant dose with 93.7, 3.87 and $1.25 \%$, respectively. According to IAEA safety standard [5, $6]$, the total dose of area A for resident farmer scenario and suburban resident scenario were exceed the dose constraint for soil cleanup or site decontamination from all pathways which is $0.3 \quad \mathrm{mSv} . \mathrm{yr}^{-1}$ above background. The total dose of area B for resident farmer scenario and suburban resident scenario were below the dose constraint but is stilled above of the dose for clearance material of order $10 \mu \mathrm{Sv}_{\mathrm{yr}}{ }^{-1}$, which means that the optimization less than $10 \mu \mathrm{Sv} . \mathrm{yr}^{-1}$ might not be warranted on radiological protection grounds. The total dose of area $\mathrm{C}$ for both scenarios were below the dose for clearance material $10 \mu \mathrm{Sv}_{\mathrm{yr}} \mathrm{yr}^{-1}$, which means that, the dose of area $\mathrm{C}$ is unwarranted on radiological protection grounds and can be release from regulatory control [6]. Figs.3-6 showed the total dose over the time and the contributions pathways of all nuclides to total dose of area A for both scenarios. From Figs.3-6, the dose appears reduction over the time until reach the zero value, but in resident farmer scenario (Figs. 3-4) the value arises slightly after many years and then back reduces again. The reason of the dose reduction attributed to the dilution of the activity concentrations of radionuclide in the soil contaminated. This dilution may come from some factors such as change in thickness of cover contaminated area, leaching and also radionuclide decay, but in case of uranium contaminated which has long half-life $4.5 \times 10^{10}$ year, the reduction belong to decay is negligible in comparison to the other two. After hundreds years, when radionuclides adsorbed in soil leached by infiltrating water (precipitation water or irrigation water) from the contaminated zone and reached to groundwater used from public, the total dose is starting rise slightly with time (as in Figs.3-4). This behavior only appears in resident farmer scenario because the groundwater contamination used from public and the dose of drink water will be large contribution to total dose.

Table 3: The results of RESRAD for calculations the dose of area $A, B$ and $C$ for both scenarios.

\begin{tabular}{|c|c|c|c|c|c|c|c|c|}
\hline Area & Scenario & $\begin{array}{c}\text { Total dose } \\
\left(\mathrm{mSv} . \mathrm{yr}^{-1}\right)\end{array}$ & \multicolumn{6}{|c|}{$\begin{array}{c}\text { Contributions pathways to total dose } \\
\left(\mathrm{mSv} . \mathrm{yr}^{-1}\right)\end{array}$} \\
\cline { 4 - 9 } & & & External & Inhalation & Plant & Meat & Milk & Soil Ingest \\
\hline (A) & $\begin{array}{c}\text { Resident } \\
\text { Farmer }\end{array}$ & 0.854 & 0.747 & $1.032 \times 10^{-2}$ & 0.05156 & $1.608 \times 10^{-3}$ & $4.096 \times 10^{-3}$ & $3.883 \times 10^{-2}$ \\
& $\begin{array}{c}\text { Suburban } \\
\text { Resident }\end{array}$ & 0.807 & 0.747 & $1.032 \times 10^{-2}$ & $1.033 \times 10^{-2}$ & - & - & $3.883 \times 10^{-2}$ \\
\hline (B) & $\begin{array}{c}\text { Resident } \\
\text { Farmer }\end{array}$ & 0.033 & 0.029433 & $3.81 \times 10^{-4}$ & $2.097 \times 10^{-3}$ & $6.54 \times 10^{-5}$ & $1.6663 \times 10^{-4}$ & $7.897 \times 10^{-4}$ \\
\cline { 2 - 9 } & $\begin{array}{c}\text { Suburban } \\
\text { Resident }\end{array}$ & 0.031 & 0.029433 & $3.81 \times 10^{-4}$ & $4.194 \times 10^{-4}$ & - & - & $7.897 \times 10^{-4}$ \\
\hline (C) & $\begin{array}{c}\text { Resident } \\
\text { Farmer }\end{array}$ & $2.15 \times 10^{-3}$ & $1.912 \times 10^{-3}$ & $2.27 \times 10^{-5}$ & $1.16 \times 10^{-4}$ & $3.61 \times 10^{-6}$ & $9.19 \times 10^{-6}$ & $8.71 \times 10^{-5}$ \\
\cline { 2 - 9 } & $\begin{array}{c}\text { Suburban } \\
\text { Resident }\end{array}$ & $2.04 \times 10^{-3}$ & $1.912 \times 10^{-3}$ & $2.27 \times 10^{-5}$ & $2.31 \times 10^{-5}$ & - & - & $8.71 \times 10^{-5}$ \\
\hline
\end{tabular}


D OSE: AllN uclides Summed,AllPathways Summed

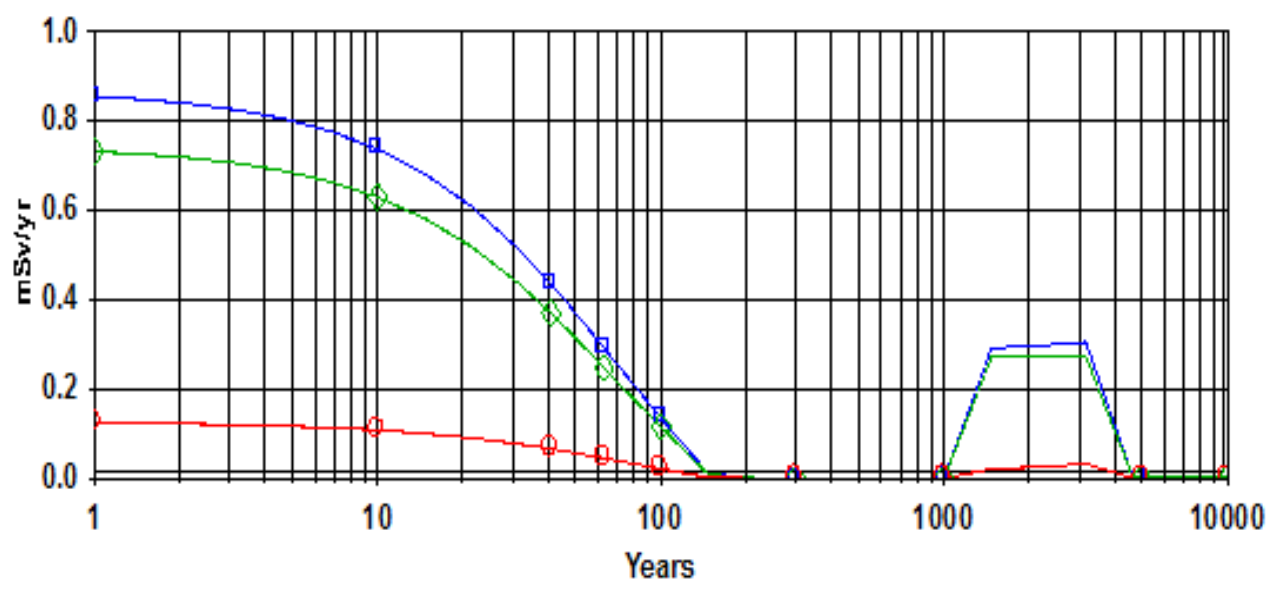

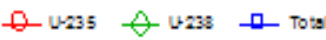

Fig.3: Annual dose over the time of area (A) for resident farmer scenario.

DOSE: AllN uc lides Summed, Component Pathways
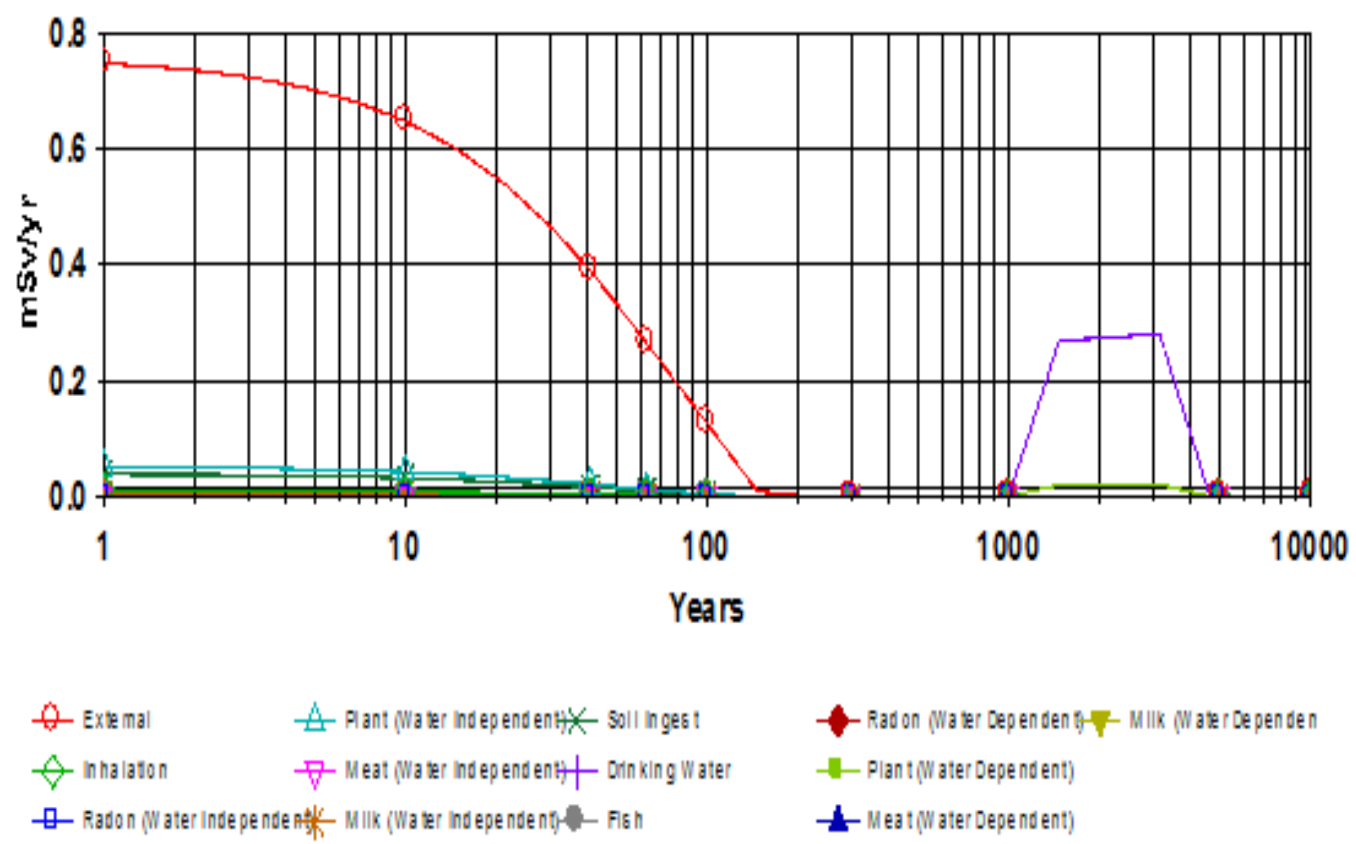

Fig.4: The contribution pathways of all nuclide to total dose of area (A) for resident farmer scenario. 
DOSE: A IIN uclides Summed,A IIPathway s Summed

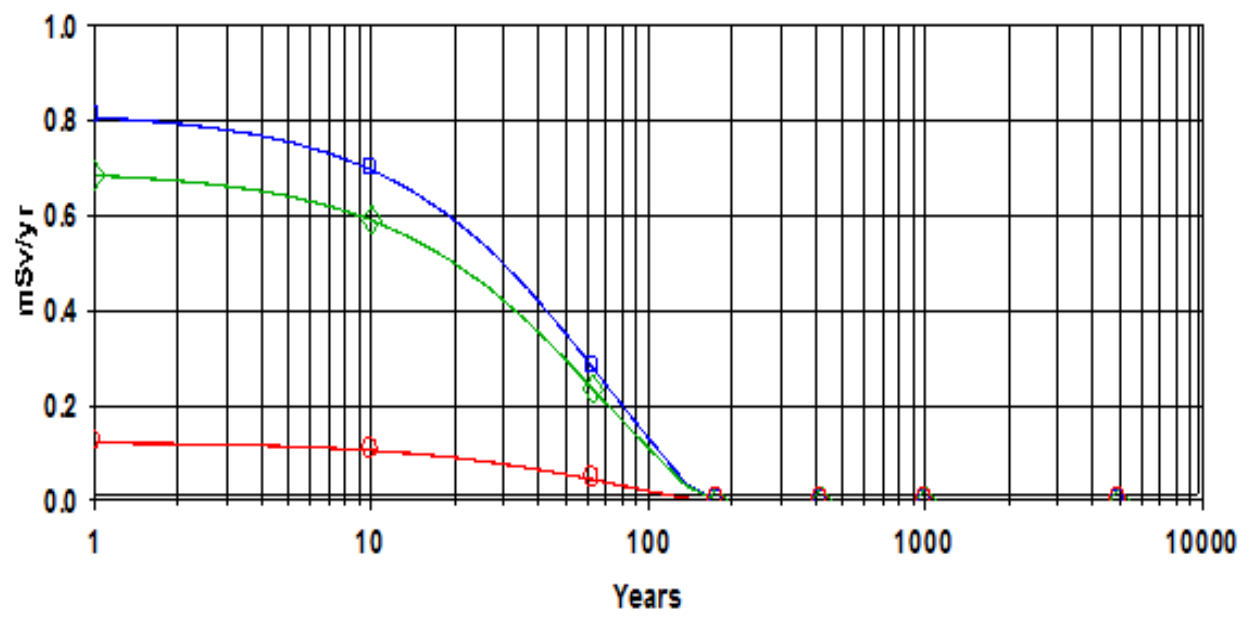

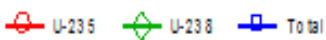

Fig.5: Annual dose over the time of area (A) for suburban resident scenario. DOSE: A IN uc lides Summed,C omponent Pathways
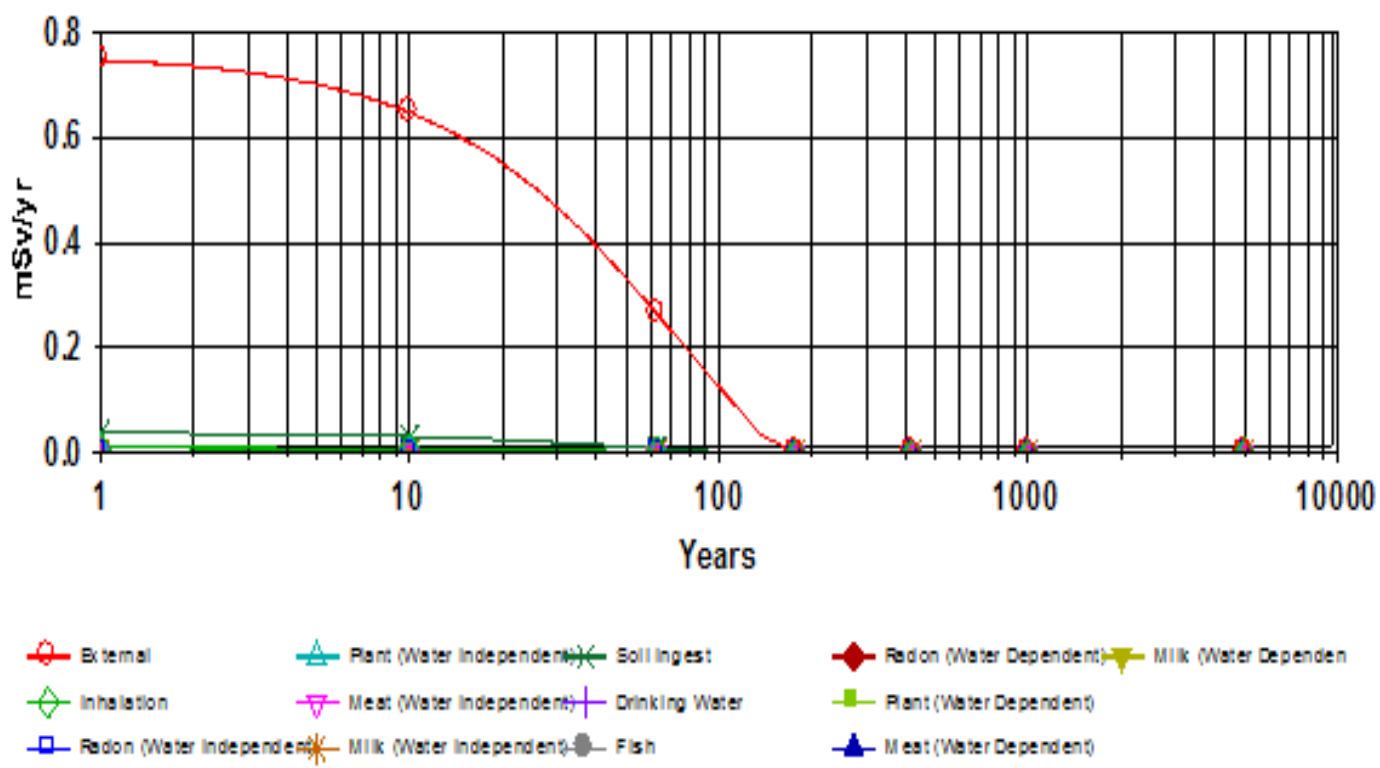

Fig.6: The contribution pathways of all nuclide to total dose of area (A) for suburban resident scenario.

\section{Conclusions}

The total dose of resident farmer scenario is higher than suburban resident scenario because it includes all environmental pathways. The early major pathway is external and the later major pathway is drink water. The total dose of area A for both scenarios was exceeded the dose constraint which is $0.3 \mathrm{mSv} \cdot \mathrm{yr}^{-1}$, the total dose of area B for both scenarios was below the dose constraint but it is stilled above the dose for clearance material which is 10 $\mu \mathrm{Sv} . \mathrm{yr}^{-1}$, while the total dose of area $\mathrm{C}$ for both scenarios were below the dose for clearance material, that means the dose of area $\mathrm{C}$ is unwarranted on radiological protection grounds and can be release from regulatory control. 


\section{References}

[1] Brice Smith. A Community Guide to Estimating Radiation Doses from Residual Radioactive Contamination. 15, 4. (2008).

[2] International Atomic Energy Agency (IAEA). "Validation of models using Chernobyl fallout data from southern Finland", IAEA-TECDOC904, (1996).

[3] C.Yu, A.J. Zielen, J. J. Cheng, D.J. LePoire, E. Gnanapragasam, S. Kamboj, J. Arnish, A. Wallo III, W.A. Williams, H. Peterson., "User's manual for RESRAD version 6". Environmental Assessment Division. United States. (2001).

[4] R.K. Chesser, B. E. Rodgers, M. Bondarkov, E. Shubber, C. J. Phillips, Bulletin of the Atomic Scientists, 65, 3 (2009) 19-33.
[5] International Atomic Energy Agency (IAEA)." Disposal of radioactive waste". sefety standerds No.SSR-5, Vienna, (2011).

[6] International Atomic Energy Agency (IAEA). "Release of site from regulatory control on termination of practices", Safety Guide. IAEA Safety Standards Series No.WS-G-5.1, Vienna, (2006).

[7] S. Al-Noori and A. Al-Sakini, Journal of the College of Basic Education for Educational and Human Sciences, Babel University, 18 (2004) 372-357.

[8] A. Al-Adili, and S. Ali, Tenth International Water Technology Conference, IWTC10 2006, Alexandria, Egypt, (2006) 1049-1055. 